\title{
OBITUARY
}

\section{SIR STEPHEN EGERTON, KCMG, MA (1932-2006)}

Stephen Egerton, who died on 7 September 2006, aged 74, was a senior member of the last generation of sons of the British Empire. Born in India, where several generations of Egertons were agents of the Raj, he was sent to England at the age of eleven to attend preparatory school and Eton. It was at Eton that he first became interested in archaeology. After national service and classics at Trinity College, Cambridge, he joined the Foreign and Commonwealth Office, in which he enjoyed a long and prominent career.

A period learning Arabic in Lebanon preceded Sir Stephen's first posting, which was to Kuwait in the late 1950s. A close connection with the Middle East was maintained throughout his diplomatic career, intermittently interrupted by a stint in Rio de Janeiro in his mid-forties and a final appointment as H. M. Ambassador to Rome. Before and between these diversions, he served variously in the Foreign Office's Arabian and Near East departments in London, at its Middle Eastern desk at the United Nations, in Libya, in Saudi Arabia, where he was ambassador in 1986-9, and twice in Iraq. His postings to Baghdad saw him there in 1963-7 and, as ambassador, in 1980-2. In this way he gained first-hand experience of Iraq in the period between the execution of General Qassem and the Ba'athist coup of 1968, and in the early years of Saddam Hussein's regime and the futile war with Iran. Across the Middle East, he observed over the course of less than fifty years the rapid development wrought by the export of oil in the region's economy and society, as well as the ascendancy of tyranny and the emergence of ever more intractable political problems.

Sir Stephen gave much time to the British School of Archaeology in Iraq. Having served as a Vice-President while ambassador in Baghdad, he joined its Council immediately upon recall to London. On retiring from the Foreign Office in 1992 he worked for various charitable and Christian causes in London but Iraq and the School held his special attention. After its forced withdrawal from Baghdad in 1990, the School felt a need for clear briefing on the diplomatic situation and advice on the prospects of a return. Sir Stephen's connections gave him inside knowledge of political and diplomatic developments and became a valuable asset to Council. His sharp-minded summaries of events, delivered in a characteristically quiet and detached manner, kept members informed at successive meetings. In 1994 Sir Stephen was re-elected a Vice President and filled that role until his death. When the termite population of the Expedition House in Baghdad began to take advantage of the empty premises, he was instrumental in ensuring the removal to safety of the School's library out of the way of the insects' malevolent gluttony. After retiring from the School's Council in 2002, he continued to serve on its Development Committee and more recently became a valuable and successful member of the Iraq Appeal Committee. $\mathrm{He}$ contributed to this journal an obituary of the Hon. Anna Plowden (Iraq 59: v-vi) and wrote a brief history of the School that awaits posting on its website.

Recently the news from Iraq was never good but even Sir Stephen was dismayed by the eventual endgame, and in 2004 he joined other prominent Middle Eastern diplomats as a signatory to open letters critical of British policy in Iraq. He left this life angry that his government had ignored the accumulated wisdom of the old Middle East hands at the Foreign Office and convinced that the latest military adventure in Iraq had gone badly wrong.

A.R.G. 